\title{
Hypoxic regulation of cytoglobin and neuroglobin expression in human normal and tumor tissues
}

\author{
Marwan Emara, A Robert Turner, Joan Allalunis-Turner
}

\begin{abstract}
Background: Cytoglobin (Cygb) and neuroglobin (Ngb) are recently identified globin molecules that are expressed in vertebrate tissues. Upregulation of Cygb and $\mathrm{Ngb}$ under hypoxic and/or ischemic conditions in vitro and in vivo increases cell survival, suggesting possible protective roles through prevention of oxidative damage. We have previously shown that Ngb is expressed in human glioblastoma multiforme (GBM) cell lines, and that expression of its transcript and protein can be significantly increased after exposure to physiologically relevant levels of hypoxia. In this study, we extended this work to determine whether Cygb is also expressed in GBM cells, and whether its expression is enhanced under hypoxic conditions. We also compared Cygb and Ngb expression in human primary tumor specimens, including brain tumors, as well as in human normal tissues. Immunoreactivity of carbonic anhydrase IX (CA IX), a hypoxia-inducible metalloenzyme that catalyzes the hydration of $\mathrm{CO}_{2}$ to bicarbonate, was used as an endogenous marker of hypoxia.
\end{abstract}

Results: Cygb transcript and protein were expressed in human GBM cells, and this expression was significantly increased in most cells following $48 \mathrm{~h}$ incubation under hypoxia. We also showed that Cygb and Ngb are expressed in both normal tissues and human primary cancers, including GBM. Among normal tissues, Cygb and $\mathrm{Ngb}$ expression was restricted to distinct cell types and was especially prominent in ductal cells. Additionally, certain normal organs (e.g. stomach fundus, small bowel) showed distinct regional co-localization of Ngb, Cygb and CA IX. In most tumors, Ngb immunoreactivity was significantly greater than that of Cygb. In keeping with previous in vitro results, tumor regions that were positively stained for CA IX were also positive for Ngb and Cygb, suggesting that hypoxic upregulation of $\mathrm{Ngb}$ and Cygb also occurs in vivo.

Conclusions: Our finding of hypoxic up-regulation of Cygb/Ngb in GBM cell lines and human tumor tissues suggests that these globin molecules may be part of the repertoire of defense mechanisms that allow cancer cells to survive in hypoxic microenvironments.

\section{Background}

A third member of the vertebrate globin family, neuroglobin ( $\mathrm{Ngb})$, was discovered in 2000 and so-named because it is primarily expressed in neuronal tissue, including retina [1]. Shortly thereafter, a fourth vertebrate globin-cytoglobin (Cygb), was described independently by three groups [2-4]. Cygb is expressed ubiquitously in human tissue [2], however, low cellular levels of Cygb and Ngb ( $\mu \mathrm{M}$ range) may have impeded their earlier discovery [5]. The amino acid sequences of

\footnotetext{
*Correspondence: joan.turner@ualberta.ca

Department of Oncology, University of Alberta, Cross Cancer Institute, 11560 University of Alberta, Edmonton, Alberta, T6G 1Z2, Canada
}

Cygb and Ngb show little similarity to that of hemoglobin $(\mathrm{Hb})$ or myoglobin $(\mathrm{Mb})(<30 \%$ and $<25 \%$ identity for Cygb and Ngb, respectively). However, amino acids that confer $\mathrm{Hb}$ and $\mathrm{Mb}$ function are conserved together with all features of the globin fold $[2,4,6]$. Unlike $\mathrm{Hb}$ and $\mathrm{Mb}$, the physiological roles of Ngb and Cygb are incompletely understood and several functions are conceivable. Ngb and Cygb may function as a Mb-type molecule to store $\mathrm{O}_{2}$ thus facilitating $\mathrm{O}_{2}$ diffusion to mitochondria $[1,6,7]$. However, the lower $\mathrm{O}_{2}$ affinity of Ngb ( $P_{50}$ of 7.5 torr under physiological conditions of $\mathrm{pH}$ and temperature) [8] compared to that of $\mathrm{Mb}\left(P_{50}\right.$ of 2-3 torr) [7] does not support an $\mathrm{O}_{2}$ storage function 
for Ngb in neuronal tissue, including retina, as only a small fraction of $\mathrm{Ngb}(\sim 12 \%)$ will be $\mathrm{O}_{2}$ saturated under normal conditions [5,8-10].

Similar to $\mathrm{Mb}$, but in contrast to $\mathrm{Ngb}$, the $\mathrm{O}_{2}$ binding of Cygb is $\mathrm{pH}$-independent [8] with higher $\mathrm{O}_{2}$ affinity values ( $P_{50}$ of $0.7-1.8$ torr) $[4,8,11]$, thus suggesting a possible physiological role to supply $\mathrm{O}_{2}$. However, due to its low concentration in vivo, Cygb function may be restricted to $\mathrm{O}_{2}$-requiring cellular reactions unrelated to mitochondrial respiration [8].

In brain, Ngb is upregulated under hypoxic/ischemic conditions [12] and may function to scavenge reactive oxygen (ROS) and nitrogen species (RNS) that are a major cause of cellular damage $[12,13]$. It has been shown that in the $\mathrm{Fe}^{2+}$-NO form, Ngb reacts more rapidly with peroxynitrite than does $\mathrm{Hb}$ [14]. Additionally, in contrast to $\mathrm{Hb}$ and $\mathrm{Mb}$, the reaction of met $\left(\mathrm{Fe}^{3+}\right)$ Ngb with peroxynitrite or hydrogen peroxide does not appear to generate the cytotoxic ferryl $\left(\mathrm{Fe}^{4+}\right)$ species, and this may contribute to cellular survival [5,14]. However, evidence for Ngb's neuroprotective function in vivo is inconsistent $[10,12,13,15-17]$. Similarly, Cygb was found to be upregulated following oxidative stress and hypoxic/ ischemic conditions in vitro and in vivo [17-21], and overexpression of Cygb in hepatic stellate cells, human SH-SY5Y neuroblastoma cells and MIN6 cells is protective $[17,22,23]$. The function of Cygb has not yet been intensively investigated. In fibroblasts and related cells expressing Cygb, its expression has been linked to collagen production and organ fibrosis [24-27]. Recently, it has been proposed that CYGB may function as a tumor suppressor gene as hypermethylation of its promoter was detected in primary human non-small cell lung cancers (48\%) [28] and oral cancers (65\%) [29], and in lung (8 of $10)$ and breast (4 of 4) cancer cell lines [30].

Glioblastoma multiforme (GBM) is the most common brain tumor among adults comprising $25 \%$ of all malignant nervous system tumors. Its resistance to multimodality therapy confers a poor prognosis and the 2-year survival rate remains only $10-25 \%$ [31]. Necrosis, and by inference hypoxia, is a diagnostic feature of human GBM tumors [32]. Hypoxic microenvironments frequently occur in human tumors, and tumor cells that are hypoxic are resistant to ionizing radiation and certain chemotherapeutic agents, are genetically unstable and metastasize frequently. Further, hypoxic microenvironments also select for tumor cells with reduced apoptotic potential. The presence of tumor hypoxia is an indicator of poor prognosis for both local-regional control and progression-free survival, and there is also evidence that hypoxia per se selects for a more aggressive tumor phenotype (reviewed in [33] and references therein). Tumor cells that survive in hypoxic microenvironments must first sense changes in $\left[\mathrm{O}_{2}\right]$ and then activate defense and adaptation mechanisms [34]. Previous work suggests that increased Ngb expression may be part of the repertoire of hypoxia defense mechanisms in normal brain. Although some studies have reported that $\mathrm{Ngb}$ is expressed exclusively in neurons but not in glia [35,36], others have reported Ngb expression in astrocytes cultured from newborn mouse brain [37], and we have shown that Ngb is expressed and upregulated by hypoxia in human GBM cell lines [38]. Here, we examined whether Cygb is also expressed in human GBM cell lines and tested whether physiologically relevant levels of hypoxia can modulate its expression as was previously demonstrated for Ngb. In addition to these in vitro analyses, we used human tissue microarrays (TMA) to assess whether $\mathrm{Ngb} / \mathrm{Cygb}$ is more broadly expressed among human primary tumors, including brain cancers, and their adjacent normal tissues. CA IX immunoreactivity was used as an endogenous marker for tissue hypoxia.

\section{Results \\ Cygb transcript and protein are expressed in GBM cells in vitro}

Cygb mRNA was detected in all aerobic GBM cell lines (controls), and when cultured under hypoxic conditions $\left(0.6 \% \mathrm{O}_{2} \times 48 \mathrm{~h}\right)$, all cell lines showed significantly increased expression of Cygb mRNA (M006x, M010b and U87T, p < 0.05; M006xLo and M059J, p < 0.001) (Figure 1). Two cell lines also showed significant increases in Cygb transcript at earlier time points (M006xLo at 6 and 24 h, p < 0.001; M059J at 24 h, $\mathrm{p}<0.01)$. Consistent with qRT-PCR results, Cygb protein was detected in all aerobic GBM cell lines with hypoxia-tolerant cells (M006x, M006xLo) showing the highest basal levels of Cygb. After $48 \mathrm{~h}$ of hypoxia, Cygb protein was significantly increased in four of five cell lines (M006xLo, M010B, and M059J, $\mathrm{p}<0.001$; U87 T, $\mathrm{p}<0.01)$, with the greatest relative increases seen in hypoxia-sensitive cells M010b and M059J (Figure 2). Cygb protein was also significantly increased in M006xLo cells after 24 h of hypoxia ( $<0.01)$. M006x cells showed a modest increase in Cygb protein after hypoxia, but this was not significant (Figure 2A). There was no correlation between the magnitude of Cygb protein increase after hypoxia and the respective basal levels of each cell line.

\section{Cygb and $\mathrm{Ngb}$ are expressed in human normal tissues and cancers}

Immunohistochemical staining of TMAs showed that $\mathrm{Ngb}$ and Cygb were variably expressed in both normal tissues and tumors. As reported previously [39], Ngb was found primarily in the cytoplasm, whereas Cygb was detected in both nucleus and cytoplasm. Among 
A

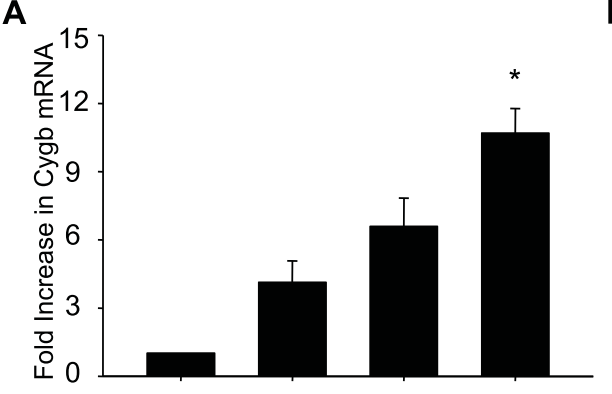

C

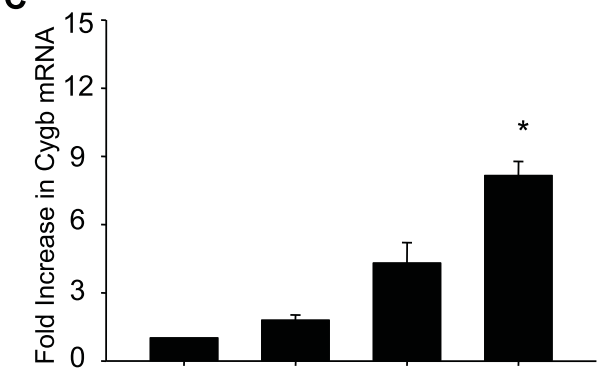

E

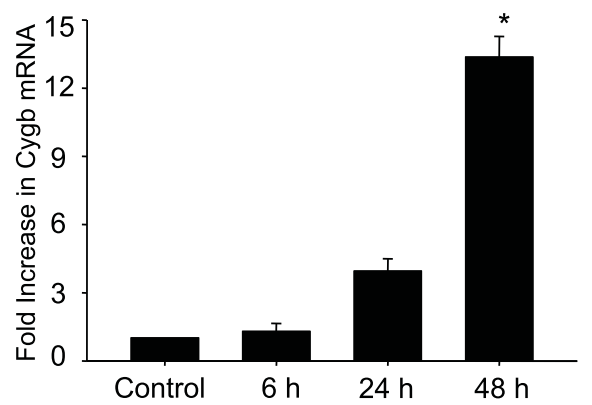

B

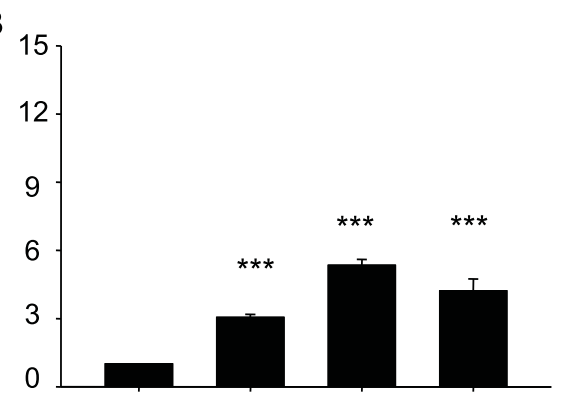

D

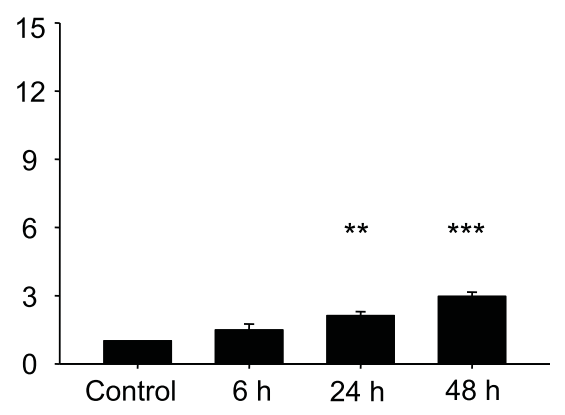

Figure 1 Cygb mRNA expression in human GBM cells. Cygb mRNA expression was assessed by qRT-PCR after exposure to hypoxia (0.6\% $\mathrm{O}_{2}$ ) for 0, 6, 24 and $48 \mathrm{~h}$. Data were expressed as fold increase relative to aerobic control ( $\mathrm{n}=4$ ). (A) M006x: (B) M006xLo; (C) M010B; (D) M059J; (E) U87T. ${ }^{*} p<0.05 ;{ }^{* *} p<0.01 ;{ }^{* * *} p<0.001$ (ANOVA).

normal tissues, Ngb expression was greatest in bone, liver, sigmoid colon, rectum and kidney, with low or negligible levels in skin, muscle and lung (Table 1). Tissues with highest Cygb expression were stomach fundus, kidney tubules and cerebellum. However, compared to $\mathrm{Ngb}$, Cygb levels were reduced overall and were low or absent in approximately half of the tissues. There was no significant correlation between levels of Cygb and $\mathrm{Ngb}$ protein in these normal tissues $(\mathrm{p}<0.07)$. However, two features of Cygb and Ngb expression in normal tissues were of particular interest. First, in several normal tissues, expression of Cygb and $\mathrm{Ngb}$ was not uniform throughout the tissue. Rather, distinct cell types or tissue structures frequently showed strong positive staining while the remainder of the tissue showed weak or absent staining. Among the structures strongly stained for Cygb were ductal cells of the breast and kidney, secretory cells of the salivary gland, white pulp/lymph of the spleen, and tips of desquamating cells found in several types of normal tissue. Ngb staining was also prominent among ductal cells of breast, endometrium, testis, prostate and salivary gland. Both Ngb and Cygb were generally absent from stroma. Second, most normal tissues showed low or absent CA IX immunoreactivity. However, stomach, small bowel, and gallbladder showed nearly identical patterns of Ngb, Cygb and CA IX staining (Figure 3).

Tumor sections showed three distinct staining patterns for Cygb/Ngb: (1) a uniform expression throughout the non-stromal tissue; (2) distinct regions of positively staining cells among otherwise negative or weakly staining tissue; or (3) densely staining focal areas frequently including intensely positive foci. Among individual tumor sections included in the 'tumor/matched normal tissue' TMA, Ngb and Cygb expression was generally increased compared to levels observed in corresponding normal tissues. As well, Cygb and Ngb immunoreactivity showed similar patterns of distribution. Most tumor 

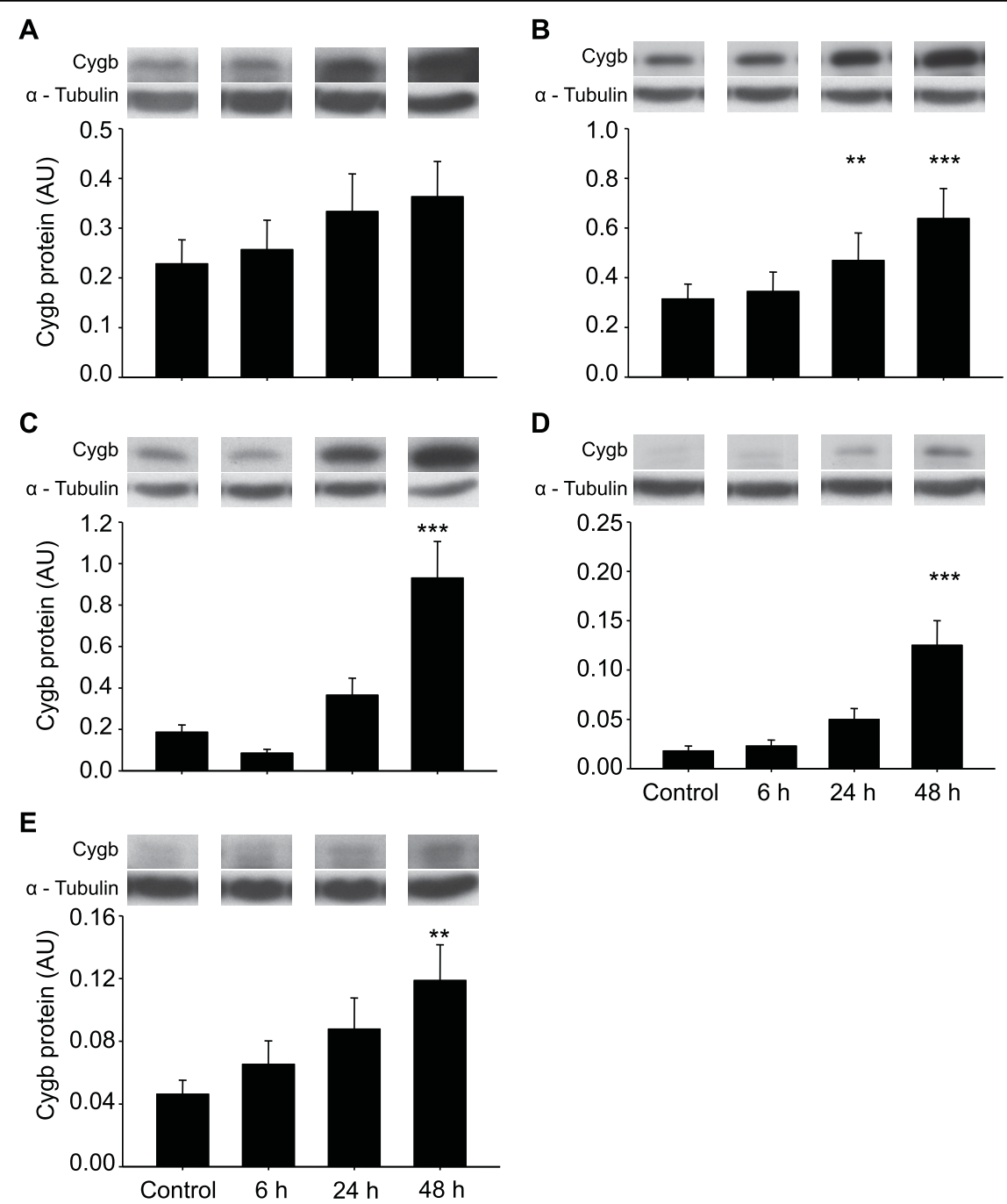

Figure 2 Cygb protein expression in human GBM cells. Cygb expression was assessed by Western blot analyses after exposure to hypoxia $\left(0.6 \% \mathrm{O}_{2}\right)$ for $0,6,24$ and $48 \mathrm{~h}(\mathrm{n}=4)$. The integrated intensities of Cygb and $\alpha$ - tubulin (control) bands were determined and expressed in arbitrary units (AU), and representative blots are shown. (A) M006x: (B) M006xLo; (C) M010B; (D) M059); (E) U87T. * $p<0.05$; ${ }^{* *} p<0.01$; ${ }^{* * *} p<$ 0.001 (ANOVA).

sections (24/29) showed low or absent CA IX immunoreactivity. However, the breast, liver, bladder and thyroid tumors that contained regions strongly positive for CA IX also showed in matching sections similar staining patterns for Cygb and Ngb (Figure 4).

\section{Cygb and $\mathrm{Ngb}$ are expressed in human brain tumors}

Both Cygb and Ngb were detected in all human brain tumors, including grades I-IV astrocytomas (Figure 5), and ependymoblastomas, gangliogliomas and oligodendrogliomas (Figure 6). Among low grade astrocytomas (Grades I and II), Ngb staining intensity was significantly greater than that of Cygb $(\mathrm{p}<0.05)$. Grade III astrocytomas and GBMs also showed relatively greater Ngb staining but these differences were not significant
(Tables 2 and 3). In tumors that showed distinct patterns of $\mathrm{Ngb}$ and Cygb expression, a comparison of tissue sections showed that these proteins were expressed in the same regions of the tumor. Large, positively staining $\mathrm{Ngb}$ and Cygb foci were commonly observed in GBM tumors. Approximately $60 \%$ of the GBM sections were also positive for CA IX staining which was confined to regions of the tumor also positive for Cygb and Ngb.

\section{Discussion}

Cygb mRNA and protein were detected in five human GBM cell lines cultured under aerobic conditions. However, basal Cygb protein levels varied $\sim 19$-fold. The rank-order of Cygb protein expression in these cell lines 
Table $1 \mathrm{Ngb}$, Cygb and CA IX expression in tissue microarrays of human solid tumors and adjacent normal tissues

\begin{tabular}{|c|c|c|c|c|}
\hline Organ & NGB & CGB & CAIX & Comments \\
\hline \multicolumn{5}{|l|}{ Normal } \\
\hline Skin & 1 & 1 & 0 & Cygb: + desquamating cells \\
\hline Breast & 1 & 1 & 0 & Ngb \& Cygb: + ductal cells \\
\hline Spleen & 2 & 1 & 0 & \\
\hline Lymph node & 3 & 1 & 1 & Ngb \& Cygb: + white pulp, lymph \\
\hline Skeletal muscle & 0 & 0 & 0 & \\
\hline Lung & 0 & 0 & 0 & \\
\hline Salivary gland & 2 & 2 & 1 & Ngb \& Cygb: + ductal cells \\
\hline Liver & 3 & 2 & 1 & \\
\hline Gallbladder & 2 & 1 & 1 & \\
\hline Pancreas & 3 & 0 & 0 & \\
\hline Tonsil & 2 & 1 & 1 & \\
\hline Esophagus & 2 & 0 & 1 & \\
\hline Stomach, antrum & 2 & 0 & 1 & Ngb \& Cygb: + ductal cells \\
\hline Stomach, fundus & 3 & 2 & 2 & Ngb \& Cygb: + ductal cells \\
\hline Small bowel & 3 & 1 & 2 & Ngb \& Cygb: + ductal cells \\
\hline Kidney, cortex & 3 & 2 & 1 & Ngb \& Cygb: + collecting ducts \& tubules; - glomeruli \\
\hline Kidney, medulla & 3 & 2 & 1 & Ngb \& Cygb: + collecting ducts \& tubules; - glomeruli \\
\hline Urinary bladder & 3 & 1 & 1 & \\
\hline Prostate & 4 & 1 & 1 & \\
\hline Testis & 1 & 0 & 0 & Ngb \& Cygb: + ductal cells \\
\hline Uterine cervix & 1 & 1 & 0 & Ngb \& Cygb: + desquamating cells, - basal layer \\
\hline Endometrium & 2 & 0 & 0 & Ngb \& Cygb: + ductal cells \\
\hline Myometrium & 2 & 1 & 1 & \\
\hline Placenta & 1 & 0 & 0 & Ngb \& Cygb: + ductal cells \\
\hline Adrenal gland & $N E$ & 2 & 0 & Cygb: + ductal cells \\
\hline Thyroid & $N E$ & $N E$ & $N E$ & \\
\hline Cerebrum & 3 & 3 & 1 & \\
\hline Cerebellum & 2 & 2 & 1 & \\
\hline \multicolumn{5}{|l|}{ Tumor } \\
\hline Skin & 1 & 1 & 1 & \\
\hline Skin & $N E$ & $N E$ & $N E$ & Ngb \& Cygb: indistinguishable from melanin \\
\hline Subcutis & 1 & 0 & 0 & \\
\hline Breast & 4 & 1 & 0 & Ngb \& Cygb: + ductal cells \\
\hline Breast & 3 & 1 & 2 & Ngb \& Cygb: + ductal cells \\
\hline \multicolumn{5}{|l|}{ Hodgkins } \\
\hline lymphoma & 3 & 2 & 0 & \\
\hline Bone & 5 & 0 & 0 & \\
\hline Lung & 3 & 0 & 0 & \\
\hline Lung & 2 & 1 & 1 & \\
\hline Liver & 4 & 2 & 0 & \\
\hline Liver & 4 & 3 & 2 & \\
\hline Liver & 5 & 2 & 2 & \\
\hline Esophagus & 2 & 0 & 1 & \\
\hline Stomach & 1 & & 0 & \\
\hline Stomach & 3 & & 1 & \\
\hline Stomach & 3 & & 0 & \\
\hline Duodenum & 1 & $? ?$ & 0 & \\
\hline Sigmoid colon & 4 & & 0 & \\
\hline Rectum & 4 & & 1 & Ngb: + ductal cells \\
\hline Kidney & 4 & & 0 & Ngb: + villi, - stroma; Cygb:+ normal \& tumor cells \\
\hline
\end{tabular}


Table $1 \mathrm{Ngb}$, Cygb and CA IX expression in tissue microarrays of human solid tumors and adjacent normal tissues (Continued)

\begin{tabular}{llll}
\hline Urinary bladder & 1 & 3 Ngb: + infiltrating cells \\
Prostate & 3 & 1 Ngb: + ductal cells \\
Testis & 2 & 0 Ngb: + ductal cells \\
Uterine cervix & 2 & 1 & 1 Ngb: some + ductal cells \\
Endometrium & 1 & 0 \\
Ovary & 2 & 0 \\
Ovary & 3 & 1 \\
Ovary & 1 & 3 \\
Thyroid & 2 & \\
\hline
\end{tabular}

Tissue microarrays constructed from cores obtained from various human solid tumors and normal adjacent tissues were purchased from IMGENEX Corporation (San Diego, CA). Immunopositive staining for Ngb, Cygb and CA IX was assessed by two observers who noted the overall tissue staining and the presence of positively stained focal regions. Each section was assigned an overall score, where $0=$ absence of positively stained cells; $1=$ a few positive cells/regions $(<$ $10 \%) ; 2=$ weak positive staining, occasional positive foci; $3=$ intermediate staining, occasional positive foci $(<50 \%) ; 4=$ strongly positive in most of the section, several positive foci; and 5 = strongly positive throughout with many intensely positive foci. Distinct features of the immunostaining patterns in individual tissue cores are noted in the comments column, where " $+"=$ positive staining, " $"$ " = negative staining and $N E=$ not evaluable.

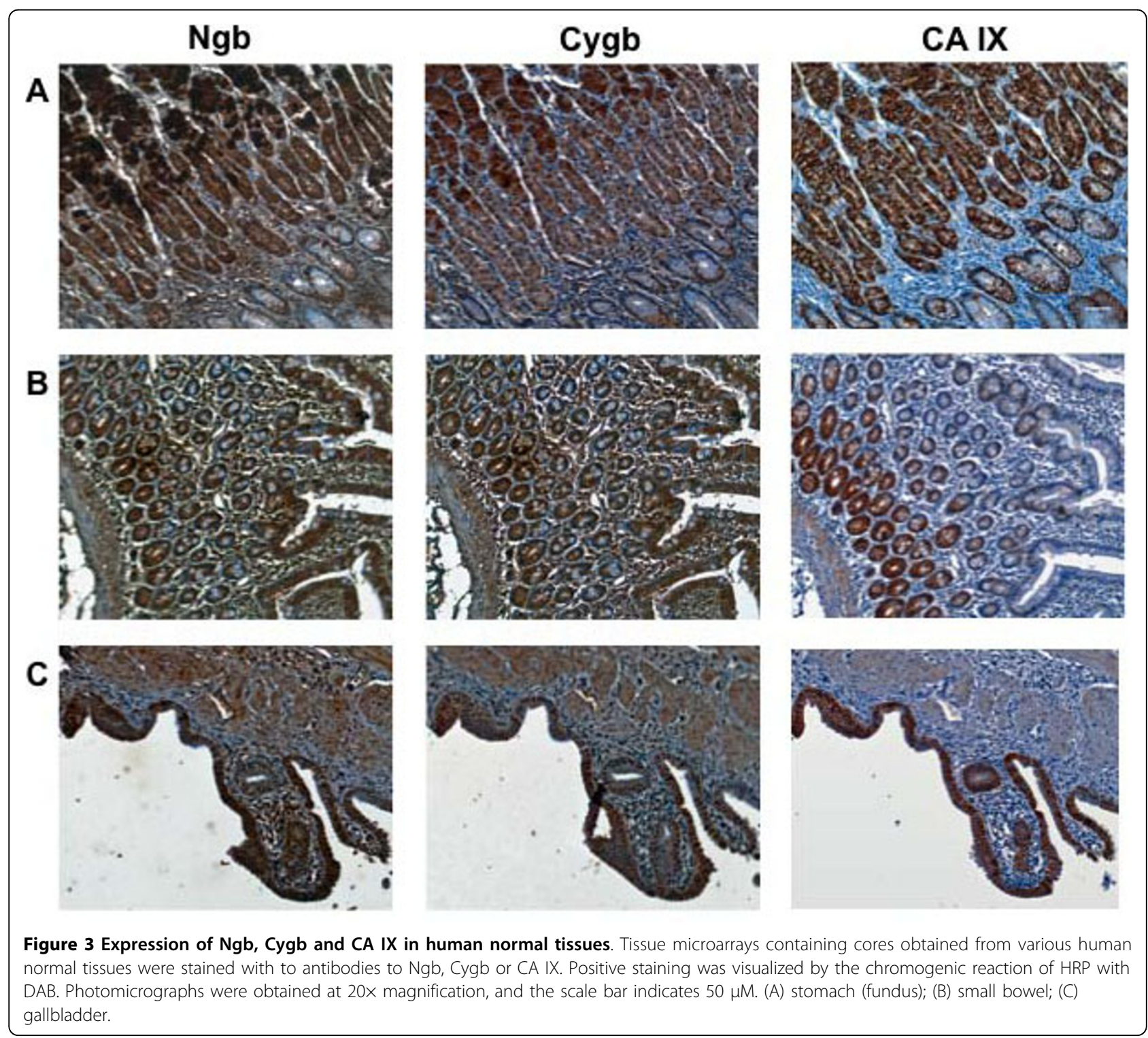




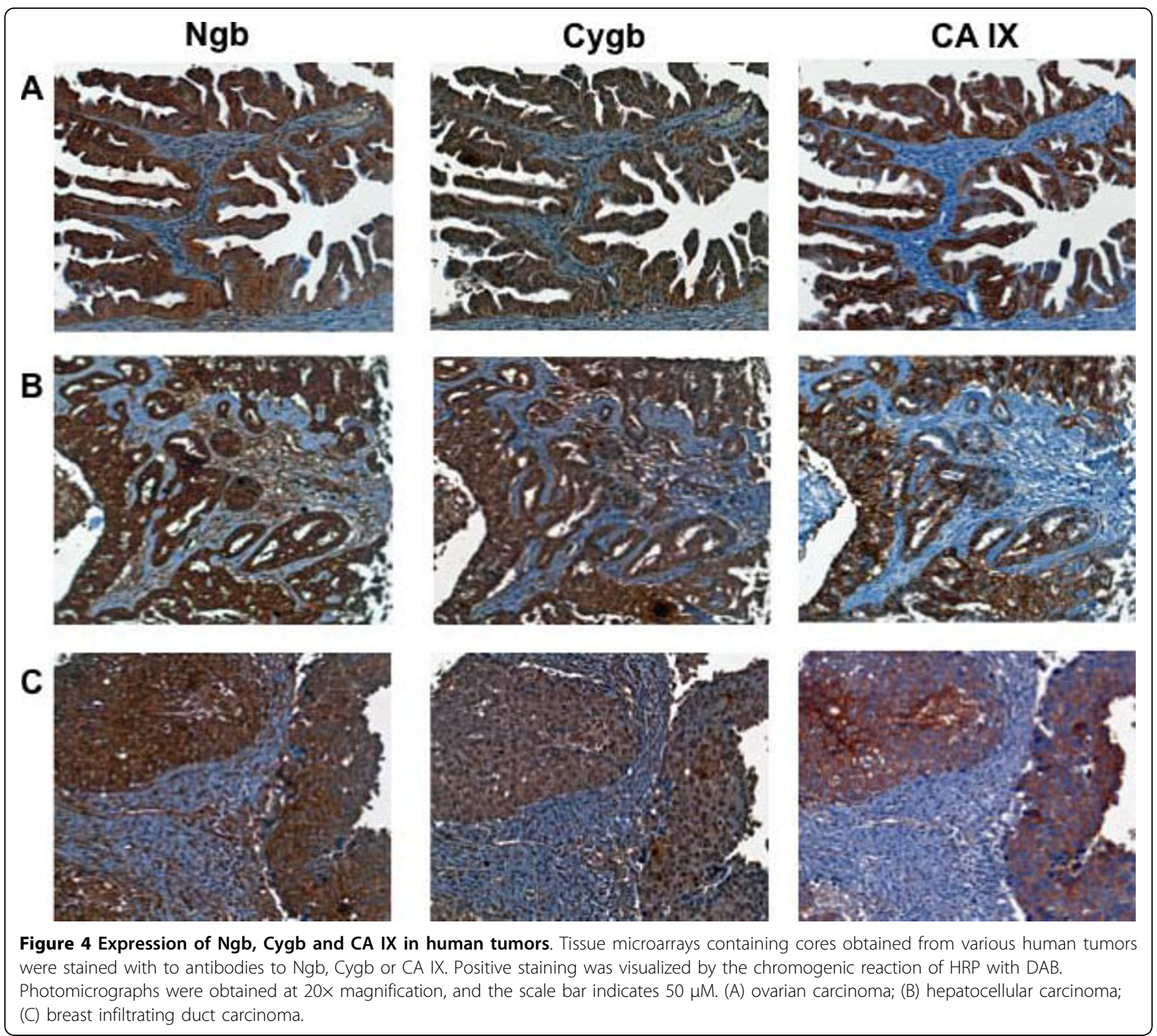

is the reverse order of that of Ngb [38], with hypoxiatolerant cells having highest Cygb, but lowest Ngb, levels. We are not aware of any other comparisons of $\mathrm{Cygb} / \mathrm{Ngb}$ concentrations in human tumor cell lines. While our results in GBM cell lines hints at a reciprocal relationship between $\mathrm{Cgyb} / \mathrm{Ngb}$, at least in GBM cell lines, this would have to be confirmed in a larger study. Co-expression of $\mathrm{Ngb}$ and $\mathrm{Cygb}$ has been reported among various structures of the anterior segment of human and canine eyes, including the cornea, iris, iridocorneal angle and the cilliary body [40], and in human retinal neurons and pigmented epithelium [41]. However, the relative expression of each protein within specific cellular structures was not quantified. In the murine retina, divergent expression of Cygb and $\mathrm{Ngb}$ has been reported, with Ngb levels being significantly higher [42].

Both Cygb transcript and protein were significantly increased in four of five GBM cell lines cultured under conditions that simulate in vivo $\mathrm{O}_{2}$ concentrations found in the hypoxic regions of human tumors [43,44]. Others have also shown that the hypoxia up-regulates Cygb transcript and protein in cell lines of neuronal origin- HN33 [18] and (SH-SY5) [45]. Hypoxia-tolerant M006x cells that express high basal level of Cygb protein showed a small, but non-significant, increase in $\mathrm{Cygb}$ after exposure to reduced $\left[\mathrm{O}_{2}\right]$. Nonetheless, M006x cells are hypoxia-responsive as we have shown that expression of another hypoxia-inducible gene, $V E G F$, can be up-regulated at equivalent levels of 


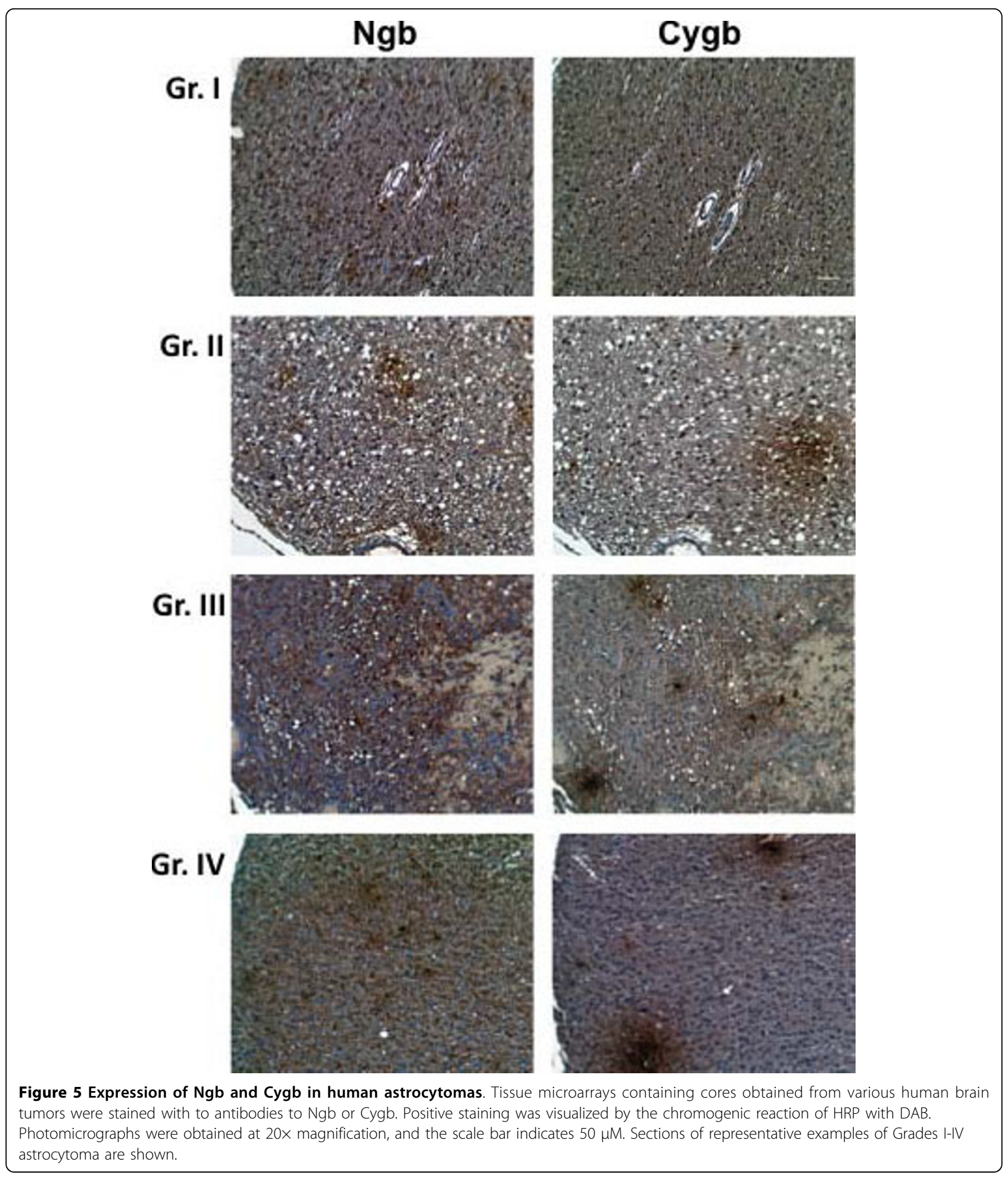

hypoxia [46]. It is interesting to note that while Cygb levels varied widely among GBM cells under aerobic condition (19-fold), when exposed to hypoxia, the differences among the cell lines were notably reduced. This would suggest that mechanisms exist to allow cells to titrate intracellular concentrations of Cygb to optimally meet the demands of given levels of oxidative stress.

In addition to GBM cell lines, Cygb expression was also observed in both low and high grade human astrocytomas, including GBM. To our knowledge, this is the 


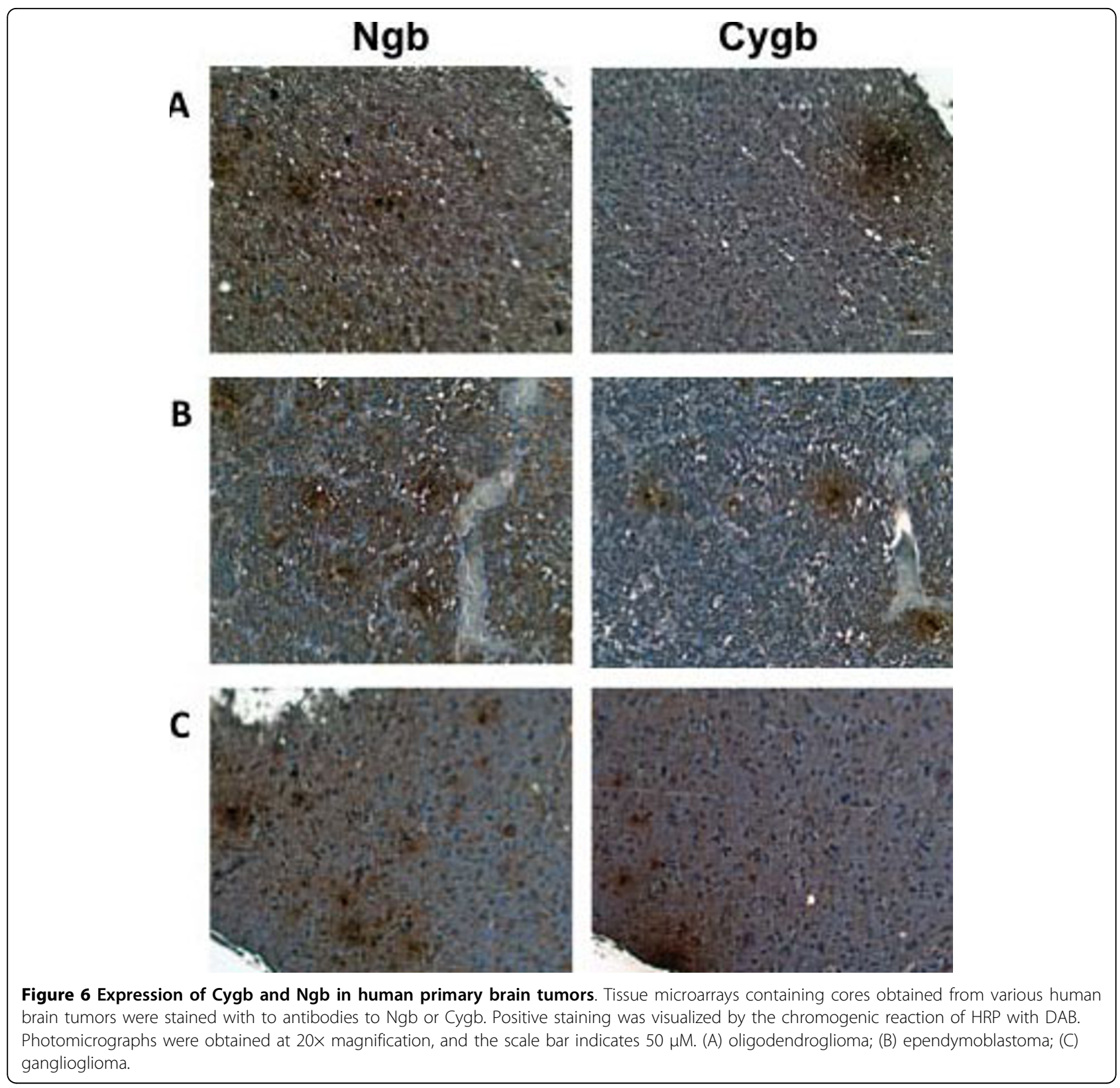

first report of Cygb expression in human primary brain cancers although high Cygb levels have been reported in brain metastases of two patients with alveolar soft part sarcomas [47]. Both Cygb transcript and protein have been reported in normal neurons, but not glia [41]. To date, there is little information concerning the coexpression of these two globin molecules in malignant human tissues. In this study, Ngb protein levels in Grades I and II astrocytomas were significantly greater than Cygb levels $(\mathrm{p}<0.05)$. There was also a trend toward increased Cygb expression as tumor grade increased from I - IV, however, this would have to be confirmed in a larger study. A similar pattern of greater
Ngb/Cygb positivity was also observed among non-brain cancers specimens examined, with Ngb expression significantly higher than that of Cygb $(p<0.001)$. Regions of necrosis are a pathognomonic feature of GBM tumors, and in many sections, enhanced Cygb/Ngb staining was observed adjacent to necrotic tissue. The microenvironment of these perinecrotic regions is likely to be severely hypoxic and thus, hypoxia-inducible proteins would be expected to be upregulated. In order to test this, we used CA IX staining as an endogenous marker of tumor hypoxia. $C A I X$ is a target gene of the hypoxia-inducible transcription factor, HIF-1 $\alpha$, and some, but not all, studies have shown a correlation 
Table 2 Ngb, Cygb and CA IX expression in tissue microarrays of human primary brain tumors

\begin{tabular}{|c|c|c|c|c|}
\hline Pathology & Grade & $\mathrm{Ngb}$ & Cygb & CA IX \\
\hline Astrocytoma of right temporal lobe & $\|$ & 2 & 1 & 0 \\
\hline Ganglioglioma of right frontal lobe & - & 3 & 1 & 0 \\
\hline Astrocytoma of left temporal lobe & $\|$ & 3 & 1 & 0 \\
\hline Astrocytoma of right frontal lobe & । & 2 & 2 & 0 \\
\hline Astrocytoma & $\|$ & 1 & 2 & 0 \\
\hline Astrocytoma & । & 3 & 2 & 0 \\
\hline Astrocytoma of frontal lobe & । & 3 & 1 & 0 \\
\hline Astrocytoma & । & 3 & 1 & 0 \\
\hline Astrocytoma of right temporal lobe & $\|$ & 2 & 1 & 0 \\
\hline Astrocytoma of brain & । & 2 & 1 & 0 \\
\hline Astrocytoma of left occipital parietal lobe & $\|$ & 2 & 3 & 0 \\
\hline Astrocytoma of right occipital lobe & $\|$ & 3 & 2 & 0 \\
\hline Ganglioglioma of left temporoparietal lobe & - & 3 & 2 & 1 \\
\hline Astrocytoma of fourth ventricle & $\|$ & 3 & 1 & 1 \\
\hline Astrocytoma of left temporal lobe & $\|$ & 5 & 2 & 0 \\
\hline Astrocytoma & $\|$ & 5 & 2 & 0 \\
\hline Astrocytoma of left parietal lobe & III & 3 & 2 & 0 \\
\hline Colloid cell hyperplasia of left brain & - & 5 & 3 & 0 \\
\hline Astrocytoma of right temporoparietal lobe & III & 4 & 2 & 0 \\
\hline Astrocytoma of frontal lobe & III & 3 & 1 & 0 \\
\hline Astrocytoma of foramen magnum & III & 1 & 0 & 2 \\
\hline Astrocytoma of left temporal lobe & $\|$ & 3 & 2 & 0 \\
\hline Astrocytoma & $\|$ & 3 & 2 & 0 \\
\hline Brain tissue & - & 3 & 4 & 1 \\
\hline Astrocytoma of right temporal lobe & $\|$ & 3 & 2 & 0 \\
\hline Astrocytoma of fourth ventricle & $\|$ & 3 & 1 & 0 \\
\hline Astrocytoma of right temporal lobe & $\|$ & 3 & 1 & 0 \\
\hline Astrocytoma & III & 2 & 3 & 0 \\
\hline Astrocytoma of left temporoparietal lobe & $\|$ & 3 & 2 & 0 \\
\hline Astrocytoma of right cerebral ventricle & $\|$ & 4 & 3 & 0 \\
\hline Oligodendroglioma of right frontal lobe & - & 4 & 4 & 0 \\
\hline Astrocytoma of brain & III & 4 & 2 & 0 \\
\hline Astrocytoma of brain & III & 3 & 4 & 0 \\
\hline Astrocytoma of left temporal lobe & $\|$ & 3 & 2 & 0 \\
\hline Astrocytoma of left temporal lobe & $\|$ & 2 & 2 & 0 \\
\hline Astrocytoma of intracranial & $\|$ & 3 & 2 & 0 \\
\hline Astrocytoma of cerebellum & III & 1 & 1 & 0 \\
\hline Astrocytoma of left temporal lobe & III & 1 & 1 & 0 \\
\hline Astrocytoma with necrosis of left frontal lobe & III & 3 & 2 & 1 \\
\hline Astrocytoma of left temporal lobe & III & 3 & 1 & 0 \\
\hline Astrocytoma of temporoparietal lobe & III & 4 & 2 & 0 \\
\hline Astrocytoma of right cerebelli & III & 2 & 2 & 0 \\
\hline Astrocytoma & III & 3 & 2 & 0 \\
\hline Astrocytoma & III & 4 & 4 & 0 \\
\hline Brain tissue with colloid cell hyperplasia of right temporal lobe & - & 4 & $N E$ & 0 \\
\hline Astrocytoma & III & 2 & 2 & 0 \\
\hline Astrocytoma of brain & III & 2 & 2 & 0 \\
\hline Astrocytoma of left frontal lobe & III & 3 & 1 & 0 \\
\hline Astrocytoma of brain & $\|$ & 4 & 3 & 0 \\
\hline Astrocytoma of left frontal lobe & III & 2 & 1 & 0 \\
\hline Astrocytoma of left temporal lobe & $\|$ & 4 & 4 & 1 \\
\hline
\end{tabular}


Table $2 \mathrm{Ngb}$, Cygb and CA IX expression in tissue microarrays of human primary brain tumors (Continued)

\begin{tabular}{|c|c|c|c|c|}
\hline Astrocytoma of left occipital & III & 3 & 3 & 0 \\
\hline Astrocytoma of left temporal lobe & III & 4 & 4 & 0 \\
\hline Astrocytoma of right temporal lobe & IV & 3 & 4 & 0 \\
\hline Astrocytoma of left temporal lobe & III & 2 & 1 & 0 \\
\hline Astrocytoma of right temporal lobe & III & 1 & 1 & 0 \\
\hline Astrocytoma of right temporal lobe & III & 3 & 1 & 0 \\
\hline Astrocytoma of fourth ventricle & IV & 3 & 2 & 0 \\
\hline Astrocytoma & $\|$ & 3 & 3 & 0 \\
\hline Astrocytoma of temporal lobe & IV & 4 & 2 & 0 \\
\hline Tumor necrosis tissue of right frontal region & - & 4 & 5 & 1 \\
\hline Astrocytoma of left occipital parietal lobe & III & 4 & 5 & 1 \\
\hline Malignant oligodendroglioma & - & 2 & 2 & 0 \\
\hline Desmoplastic astrocytoma of left temporoparietal lobe & - & 3 & 5 & 0 \\
\hline Astrocytoma of intracranial & $\|$ & 3 & 2 & 0 \\
\hline Ependymoblastoma of posterior fossa & - & 3 & 2 & 0 \\
\hline Ependymoma of brain parietooccipital & - & 3 & 3 & 0 \\
\hline Ependymoma of brain & - & 3 & 2 & 0 \\
\hline Ependymoma of right parietal lobe & - & 4 & 4 & 0 \\
\hline Ependymoma of intracranial & - & 3 & 3 & 0 \\
\hline Matched cerebrum tissue of 1st tumor & - & 2 & 2 & 0 \\
\hline Matched cerebrum tissue of 2 nd tumor & - & 3 & 3 & 0 \\
\hline Matched cerebrum tissue of 3 rd tumor & - & 4 & 4 & 1 \\
\hline Matched cerebrum tissue of 4 th tumor & - & 1 & 2 & 0 \\
\hline Normal cerebrum tissue & - & 1 & 2 & 0 \\
\hline Normal cerebrum tissue & - & 1 & 1 & 0 \\
\hline Normal cerebrum tissue & - & 5 & 2 & 0 \\
\hline Normal cerebrum tissue & - & 2 & 3 & 0 \\
\hline Normal cerebrum tissue & - & 3 & 4 & 0 \\
\hline Normal cerebellum tissue & - & 3 & 1 & 0 \\
\hline
\end{tabular}

Tissue microarrays constructed from cores obtained from various human primary brain cancers and normal adjacent brain were purchased from IMGENEX Corporation (San Diego, CA). Immunopositive staining for Ngb, Cygb and CA IX was assessed by two observers who noted the overall tissue staining and the presence of positively stained focal regions. Each section was assigned an overall score, where $0=$ absence of positively stained cells; $1=\mathrm{a}$ few positive cells/ regions $(<10 \%) ; 2=$ weak positive staining, occasional positive foci; $3=$ intermediate staining, occasional positive foci $(<50 \%)$; $4=$ strongly positive in most of the section, several positive foci; and $5=$ strongly positive throughout with many intensely

between CA IX expression and tumor hypoxia (reviewed in [48]). In these TMAs, tumor regions that were positive for CA IX also showed Cygb/Ngb expression. However, not all regions that were $\mathrm{Ngb} / \mathrm{Cygb}$ positive also showed CA IX immunoreactivity. A possible explanation is the fact that in tumors, CA IX expression is generally associated with perinecrotic regions that are likely to be severely hypoxic [48]. In contrast, the up-regulation of both Ngb and Cygb expression has been observed at relatively higher $\mathrm{O}_{2}$ tensions $\left(\sim 1 \% \mathrm{O}_{2}\right)$.

In addition to the brain tumor TMAs, we also studied $\mathrm{Ngb}$ and Cygb expression in several normal tissues and their malignant counterparts. Although Cygb has been described as a ubiquitous cellular globin, it was reduced or absent from many normal tissues, but prominent in ductal cells in gallbladder, stomach, small bowel and kidney. Shigematsu et al. [49] previously reported a similar distribution for Cgyb in normal tissues. However, the most striking feature observed in our study was the distinct regional co-localization of $\mathrm{Ngb}, \mathrm{Cygb}$ and $\mathrm{CA}$ IX in several normal tissues, including stomach, small bowel and salivary gland. CA IX expression in human alimentary tract has been previously described [50], but to our knowledge, this is the first demonstration of coexpression of $\mathrm{Ngb} / \mathrm{Cygb} / \mathrm{CA}$ IX in human tissue.

To corroborate these protein expression patterns, we queried NCBI Gene Expression Omnibus (GEO) Profiles-a public repository of microarray gene expression data [51]. This search indicated that there is robust expression of Ngb and Cygb mRNA in a variety of human primary non-malignant and tumor samples [See Additional files 1 and 2]. However, there is considerable heterogeneity in the expression $\mathrm{Ngb}$ and Cygb mRNA, both within a given histological type of non-malignant or tumor tissue, and among different types of tissue. 
Table 3 Assessment of Cygb, Ngb and CA IX expression in tissue microarrays of human glioblastoma multiforme tumors

\begin{tabular}{|c|c|c|c|c|}
\hline Pathology & Grade & $\mathrm{Ngb}$ & Cygb & CA IX \\
\hline Glioblastoma & IV & 3 & 1 & 1 \\
\hline Glioblastoma & IV & 3 & 1 & 1 \\
\hline Pleomorphic glioblastoma & IV & 5 & 4 & 1 \\
\hline Pleomorphic glioblastoma & IV & 5 & 4 & 1 \\
\hline Glioblastoma & IV & 3 & 1 & 2 \\
\hline Glioblastoma & IV & 2 & 1 & 1 \\
\hline Pleomorphic glioblastoma & IV & 5 & 2 & 2 \\
\hline Pleomorphic glioblastoma & IV & 5 & 2 & 2 \\
\hline Glioblastoma & IV & 2 & 2 & 1 \\
\hline Glioblastoma & IV & 2 & 2 & 1 \\
\hline Glioblastoma (sparse) & IV & 2 & 2 & 0 \\
\hline Glioblastoma (necrotic tissue) & IV & 4 & 5 & 1 \\
\hline Glioblastoma (necrotic tissue) & IV & 4 & 5 & 1 \\
\hline Pleomorphic glioblastoma & IV & 4 & 3 & 0 \\
\hline Pleomorphic glioblastoma & IV & 4 & 3 & 0 \\
\hline Glioblastoma & III & 2 & 2 & 0 \\
\hline Glioblastoma & III & 2 & 2 & 0 \\
\hline Glioblastoma & IV & 2 & 3 & 1 \\
\hline Glioblastoma & IV & 3 & 2 & 1 \\
\hline Glioblastoma & IV & 3 & 2 & 1 \\
\hline Glioblastoma & III & 5 & 4 & 0 \\
\hline Glioblastoma & III & 5 & 4 & 0 \\
\hline Glioblastoma & IV & 5 & 2 & 1 \\
\hline Glioblastoma & IV & 5 & 2 & 2 \\
\hline Glioblastoma & IV & 4 & 2 & 0 \\
\hline Glioblastoma & IV & 5 & 2 & 1 \\
\hline Glioblastoma & IV & 5 & 2 & 3 \\
\hline Glioblastoma & IV & 3 & 2 & 0 \\
\hline Glioblastoma & IV & 3 & 3 & 1 \\
\hline Glioblastoma & IV & 4 & 3 & 0 \\
\hline Glioblastoma & IV & 4 & 2 & 2 \\
\hline Glioblastoma & IV & 4 & 2 & 0 \\
\hline Glioblastoma & IV & 3 & 2 & 0 \\
\hline Glioblastoma & III & 5 & 2 & 0 \\
\hline Glioblastoma & III & 5 & 3 & 1 \\
\hline Glioblastoma & IV & 4 & 2 & 3 \\
\hline Glioblastoma & IV & 4 & 2 & 0 \\
\hline Glioblastoma & IV & 5 & 2 & 0 \\
\hline Pleomorphic glioblastoma & IV & 4 & 2 & 1 \\
\hline Pleomorphic glioblastoma & IV & 4 & 3 & 2 \\
\hline Glioblastoma & III & 4 & 3 & 2 \\
\hline Glioblastoma & III & 4 & 3 & 2 \\
\hline Glioblastoma & III & 4 & 2 & 0 \\
\hline Glioblastoma & III & 4 & 3 & 0 \\
\hline Glioblastoma & IV & 4 & 4 & 0 \\
\hline Glioblastoma & IV & 5 & 3 & 0 \\
\hline Glioblastoma & IV & 4 & 3 & 0 \\
\hline Pleomorphic glioblastoma & IV & 5 & 4 & 1 \\
\hline Pleomorphic glioblastoma & IV & 5 & 4 & 1 \\
\hline
\end{tabular}

Table 3 Assessment of Cygb, Ngb and CA IX expression in tissue microarrays of human glioblastoma multiforme tumors (Continued)

\begin{tabular}{|c|c|c|c|c|}
\hline Glioblastoma & III & 3 & 2 & 0 \\
\hline Glioblastoma & III & 3 & 2 & 0 \\
\hline Glioblastoma & IV & 4 & 3 & \\
\hline Glioblastoma & IV & 4 & 3 & 3 \\
\hline Glioblastoma & IV & 4 & 4 & \\
\hline Glioblastoma & IV & 3 & 2 & \\
\hline Glioblastoma & IV & 4 & 3 & \\
\hline Glioblastoma & IV & 3 & 4 & \\
\hline Glioblastoma & IV & 3 & 4 & \\
\hline Glioblastoma & IV & 2 & 3 & \\
\hline Glioblastoma & IV & 3 & 2 & \\
\hline Adjacent normal brain & - & 4 & 3 & \\
\hline Adjacent normal brain & - & 3 & 2 & \\
\hline Adjacent normal brain & - & 3 & 4 & 0 \\
\hline
\end{tabular}

Although Ngb and Cygb were discovered almost a decade ago, their functions continue to be explored. Currently, evidence from both in vitro and in vivo model systems indicates that these globins play important roles in protecting cells from death during ischemic insult (hypoxia-reperfusion), oxygen/glucose deprivation, or exogenous oxidative stress [17,22,45,52-55]. Recently, Raychaudhuri et al. [56] used experimental and computational analyses to show that Ngb overexpression protects SH-SY5Y neuroblastoma cells from cell death by inhibiting the initiation of the intrinsic apoptotic pathway. They hypothesize that the ability of Ngb to bind to cytochrome $c$ provides a mechanism whereby Ngb could interfere with cytochrome $c$-induced activation caspase9 , a critical step required for initiation of the intrinsic apoptotic cascade. Accordingly, Ngb or Cygb expression may provide the same pro-survival effect in tumors in which both chronic and intermittent hypoxia (ischemia/ reperfusion) as well as glucose deprivation commonly occur (reviewed in [33].

\section{Conclusions}

We showed two novel globins-Cygb and Ngb, are expressed in human primary tumors and cell lines. Their up-regulation by hypoxia in vitro, and their association with an endogenous hypoxia marker in tumor tissue 
sections suggests that these globins may contribute to the pro-survival mechanisms utilized by these cancers to survive under conditions of oxidative stress.

\section{Methods}

\section{Cell lines and in vitro culture conditions}

The origin and characterization of the GBM cell lines have been published previously: the M059J (ATCC number CRL2366) and M010b cell lines are hypoxia-sensitive; the M006x and M006xLo cell lines are hypoxia-tolerant $[46,57,58]$. The U87T cell line was established following serial in vivo selection in a glioma mouse model [59] and was kindly provided by Dr. Donna Senger (University of Calgary). Its relative sensitivity to hypoxia has not been determined. All cells were maintained as monolayer cultures in DMEM/F12 media supplemented with 10\% fetal calf serum and $1 \mathrm{mM}$ L-glutamine in a humidified atmosphere of $5 \% \mathrm{CO}_{2}$ in air at $37^{\circ} \mathrm{C}$. All tissue culture supplies were purchased from GIBCO.

\section{Generation of hypoxia in vitro}

A de-gassing manifold was used to generate hypoxia in vitro [60]. Exponential phase cells $\left(\sim 2 \times 10^{5}\right)$ were seeded onto $60-\mathrm{mm}$ glass plates and then incubated under standard laboratory culture conditions $\left(5 \% \mathrm{CO}_{2}\right.$ in air) for 4 days. The medium was then replenished and the plates were transferred to aluminum chambers from which the air was evacuated and then replaced with $5 \% \mathrm{CO}_{2}$ /balance $\mathrm{N}_{2}$ until an $\mathrm{O}_{2}$ tension of $0.6 \%$ was achieved. The sealed, air-tight aluminum chambers were then incubated at $37^{\circ} \mathrm{C}$ for $6-48 \mathrm{~h}$. At the end of each incubation interval, the aluminum chambers were unsealed, the tissue culture plates removed, RNA and protein isolated from the cells as described in Section 2.4 and 2.5 .

\section{Quantitative real-time reverse transcription-PCR}

Total RNA from cultured cell lines was isolated using the RNeasy mini kit (QIAGEN). Reverse transcription (RT) was carried out with $1 \mu \mathrm{g}$ total RNA. per $20 \mathrm{ml}$ reaction volume using QuantiTect reverse transcription kit (QIAGEN). RT experiments were performed with GeneAmp PCR system 9700 (Applied Biosystems). Quantitative real-time PCR (qRT-PCR) analysis was performed with a $7900 \mathrm{HT}$ Fast Real-Time PCR System (Applied Biosystems) using TaqMan fast universal PCR master mix and a validated TaqMan Gene Expression assay (Applied Biosystems) for the human CYGB gene (assay ID: Hs00370478_ml). Human 18 S rRNA gene (part no.: 4333760T, Applied Biosystems) was used as endogenous control. Amplification data were analyzed with SDS RQ Manager 1.2. Relative quantities of Cygb transcripts were normalized against relative quantities of the $18 \mathrm{~S}$ rRNA transcripts, and fold-expression changes calculated using the expression $2^{-\Delta \Delta C T}$.

\section{Western blotting}

Whole-cell lysates were prepared using complete LysisM buffer (Roche Diagnostics) and protein content determined using a protein assay kit (Pierce). Equal amounts of protein $(50 \mu \mathrm{g})$ were resolved using $13 \%$ SDS -PAGE under reducing condition and electro-transferred to polyvinylidene difluoride membranes (Bio-Rad Laboratories, CA). Membranes were blocked with 5\% skim milk then incubated with Cygb antibody (1:60 rabbit anti-human polyclonal antibody [sc-66855] Santa Cruz Biotechnology, Inc, CA) or $\alpha$-tubulin antibody (1:5000, mouse anti-human $\alpha$-tubulin monoclonal antibody, SIGMA) as loading control. Membranes were incubated with polyclonal goat anti-rabbit IgG $(\mathrm{H}+\mathrm{L})$ horseradish peroxidase (HRP)-conjugated (1:25000, Jackson ImmunoResearch Laboratories, Inc. PA) or polyclonal goat anti-mouse IgG HRP-conjugated (1:6000, DakoCytomation Denmark A/S, Demark). Bound proteins were detected using chemiluminescence reagents (SuperSignal West Pico Chemiluminescent Substrate, Thermo Scientific, IL) and visualized by exposing to X-ray film (Fuji Photo Film, Japan) that was developed using a Kodak XOMAT 2000A processor (Eastman Kodak Company, Japan). X-ray films were scanned using an Artixscan 1800f scanner (MICROTEK, TAIWAN) and bands were analyzed using Quantity One 1-D analysis software (BioRad Laboratories). The integrated areas of bands were determined and expressed in arbitrary units (AU).

\section{Tissue micorarrays and immunostaining}

Tissue microarrays (TMA) constructed from tissue sections obtained from various human solid tumors and normal adjacent tissues (IMH-346), GBMs (IMT-01256), and various brain cancers and normal adjacent tissues (IMT-01257) were purchased from IMGENEX Corporation (San Diego, CA). The manufacturer confirmed the glial origin of the brain tumors included on the arrays using immunoreactivity to anti-glial fibrillary acid protein. Immunohistochemical staining was performed according to manufacturer's protocol with modifications. TMA slides were deparaffinized by incubating in a dry oven at $62^{\circ} \mathrm{C}$ for $1.5 \mathrm{~h}$, dewaxed in xylene, and then hydrated. TMAs were processed for antigen retrieval, incubated with blocking buffer $(0.5 \mathrm{M}$ glycine in PBS$0.2 \%$ brij35) and then with antibodies to Ngb (1:150, mouse anti-human Ngb monoclonal antibody, BioVendor Laboratory Medicine Inc., Czech Republic), Cygb (1:150, mouse anti-human Cygb monoclonal antibody, Abnova Corporation, Taiwan) or Ca IX (1:600, rabbit anti-human CA IX, Novus Biologicals, Inc., USA). The 
specificity of the primary antibodies was demonstrated by using Cygb or Ngb peptides to block positive immunostaining [Additional file 3]. Tissue endogenous peroxidase was quenched by incubation with $3 \% \mathrm{H}_{2} \mathrm{O}_{2}$ for $15 \mathrm{~min}$. Tissue sections were incubated with HRP-conjugated goat anti-mouse antibodies (DakoCytomation) and positive staining visualized by the chromogenic reaction of HRP with DAB (3,3' diaminobenzidine tetrahydrochloride) (DakoCytomation). Relative Cygb and $\mathrm{Ngb}$ expression in each tissue core was assessed by two observers who noted the overall tissue staining and the presence of positively stained focal regions. Each section was assigned an overall score, where $0=$ absence of positively stained cells; $1=\mathrm{a}$ few positive cells/regions $(<10 \%) ; 2$ = weak positive staining, occasional positive foci; 3 = intermediate staining, occasional positive foci $(<50 \%) ; 4=$ strongly positive in most of the section, several positive foci; and $5=$ strongly positive throughout with many intensely positive foci.

\section{Statistics}

Data from four replicate experiments were expressed as mean \pm standard error. Statistical analyses were performed using SigmaPlot 11 software (Systat Software, Inc). Differences between groups were compared using one-way ANOVA or ANOVA on ranks (Kruskal-Wallis) based on the normality and equal variance tests. To determine exactly which groups are different and the size of the difference, multiple comparisons versus control group were carried out using Bonferroni t-test and Dunnett's or Dunn's test for one-way ANOVA and ANOVA on ranks (Kruskal- Wallis), respectively, as post-hoc tests.

\section{Additional material}

Additional file 1: Table S1. Results of GEO profiles query of Cygb expression in human non-malignant and tumor tissues. This table provides the range of the intra-sample percentile rank values for Cygb expression in a variety of human primary tissue samples. These values provide an indication of the relative expression of Cygb compared to that of all other genes expressed in that sample.

Additional file 2: Table S2. Results of GEO profiles query of Ngb expression in human non-malignant and tumor tissues. This table provides the range of the intra-sample percentile rank values for $\mathrm{Ngb}$ expression in a variety of human primary tissue samples. These values provide an indication of the relative expression of $\mathrm{Ngb}$ compared to that of all other genes expressed in that sample.

Additional file 3: Figure S1. Antibody specificity demonstrated by competitive immunostaining. This figure shows that incubation of primary Ngb and Cygb antibodies with the relevant recombinant proteins effectively blocked positive immunostaining.

\section{Acknowledgements}

We thank Bonnie Andrais for assistance with tissue culture and Gerry Barron for help with the preparation of the photomicrographs. This study was supported by an award from the Canadian Cancer Society Research Institute with funds provided by the Canadian Cancer Society.

\section{Authors' contributions}

EM and JAT conceived of the study. EM performed the in vitro analyses and TMA immunostaining, did the statistical analyses and wrote the first draft of the manuscript. ART and JAT analyzed the TMAs. All authors contributed to the final draft of the manuscript.

\section{Competing interests}

The authors declare that they have no competing interests.

Received: 17 March 2010 Accepted: 9 September 2010

Published: 9 September 2010

\section{References}

1. Burmester $T$, Weich $B$, Reinhardt $S$, Hankeln T: A vertebrate globin expressed in the brain. Nature 2000, 407(6803):520-523.

2. Burmester T, Ebner B, Weich B, Hankeln T: Cytoglobin: a novel globin type ubiquitously expressed in vertebrate tissues. Mol Biol Evol 2002, 19(4):416-421.

3. Kawada N, Kristensen DB, Asahina K, Nakatani K, Minamiyama Y, Seki S, Yoshizato K: Characterization of a stellate cell activation-associated protein (STAP) with peroxidase activity found in rat hepatic stellate cells. J Biol Chem 2001, 276(27):25318-25323.

4. Trent JT, Hargrove MS: A ubiquitously expressed human hexacoordinate hemoglobin. J Biol Chem 2002, 277(22):19538-19545.

5. Fago A, Hundahl C, Malte H, Weber RE: Functional properties of neuroglobin and cytoglobin. Insights into the ancestral physiological roles of globins. IUBMB Life 2004, 56(11-12):689-696.

6. Pesce A, Bolognesi M, Bocedi A, Ascenzi P, Dewilde S, Moens L, Hankeln T, Burmester T: Neuroglobin and cytoglobin. Fresh blood for the vertebrate globin family. EMBO Rep 2002, 3(12):1146-1151.

7. Wittenberg JB, Wittenberg BA: Myoglobin function reassessed. J Exp Biol 2003, 206(Pt 12):2011-2020

8. Fago A, Hundahl C, Dewilde S, Gilany K, Moens L, Weber RE: Allosteric regulation and temperature dependence of oxygen binding in human neuroglobin and cytoglobin. Molecular mechanisms and physiological significance. J Biol Chem 2004, 279(43):44417-44426.

9. Wangsa-Wirawan ND, Linsenmeier RA: Retinal oxygen: fundamental and clinical aspects. Arch Ophthalmol 2003, 121(4):547-557.

10. Hundahl C, Stoltenberg M, Fago A, Weber RE, Dewilde S, Fordel E, Danscher G: Effects of short-term hypoxia on neuroglobin levels and localization in mouse brain tissues. Neuropathol Appl Neurobiol 2005, 31(6):610-617.

11. Hamdane D, Kiger L, Dewilde S, Green BN, Pesce A, Uzan J, Burmester T, Hankeln T, Bolognesi M, Moens $L$, et al: The redox state of the cell regulates the ligand binding affinity of human neuroglobin and cytoglobin. J Biol Chem 2003, 278(51):51713-51721.

12. Sun $Y$, Jin $K$, Mao XO, Zhu Y, Greenberg DA: Neuroglobin is up-regulated by and protects neurons from hypoxic-ischemic injury. Proc Natl Acad Sci USA 2001, 98(26):15306-15311.

13. Sun Y, Jin K, Peel A, Mao XO, Xie L, Greenberg DA: Neuroglobin protects the brain from experimental stroke in vivo. Proc Natl Acad Sci USA 2003, 100(6):3497-3500.

14. Herold S, Fago A, Weber RE, Dewilde S, Moens L: Reactivity studies of the $\mathrm{Fe}$ (III) and $\mathrm{Fe}$ (II)NO forms of human neuroglobin reveal a potential role against oxidative stress. J Biol Chem 2004, 279(22):22841-22847.

15. Hundahl C, Kelsen J, Kjaer K, Ronn LC, Weber RE, Geuens E, Hay-Schmidt A, Nyengaard JR: Does neuroglobin protect neurons from ischemic insult? A quantitative investigation of neuroglobin expression following transient MCAo in spontaneously hypertensive rats. Brain Res 2006, 1085(1):19-27.

16. Fraser J, de Mello LV, Ward D, Rees HH, Williams DR, Fang Y, Brass A, Gracey AY, Cossins AR: Hypoxia-inducible myoglobin expression in nonmuscle tissues. Proc Natl Acad Sci USA 2006, 103(8):2977-2981.

17. Fordel $E$, Thiis $L$, Martinet W, Lenjou M, Laufs T, Van Bockstaele D, Moens $L$, Dewilde S: Neuroglobin and cytoglobin overexpression protects human SH-SY5Y neuroblastoma cells against oxidative stress-induced cell death. Neurosci Lett 2006, 410(2):146-151.

18. Fordel E, Geuens E, Dewilde S, Rottiers P, Carmeliet P, Grooten J, Moens L: Cytoglobin expression is upregulated in all tissues upon hypoxia: an in 
vitro and in vivo study by quantitative real-time PCR. Biochem Biophys Res Commun 2004, 319(2):342-348.

19. Burmester T, Haberkamp M, Mitz S, Roesner A, Schmidt M, Ebner B, Gerlach F, Fuchs C, Hankeln T: Neuroglobin and cytoglobin: genes, proteins and evolution. IUBMB Life 2004, 56(11-12):703-707.

20. Guo X, Philipsen S, Tan-Un KC: Study of the hypoxia-dependent regulation of human CYGB gene. Biochem Biophys Res Commun 2007, 364(1):145-150.

21. Li D, Chen XQ, Li WJ, Yang YH, Wang JZ, Yu AC: Cytoglobin up-regulated by hydrogen peroxide plays a protective role in oxidative stress. Neurochem Res 2007, 32(8):1375-1380.

22. Stagner Jl, Parthasarathy SN, Wyler K, Parthasarathy RN: Protection from ischemic cell death by the induction of cytoglobin. Transplant Proc 2005, 37(8):3452-3453

23. Xu R, Harrison PM, Chen M, Li L, Tsui TY, Fung PC, Cheung PT, Wang G, $\mathrm{Li} \mathrm{H}$, Diao Y, et al: Cytoglobin overexpression protects against damageinduced fibrosis. Mol Ther 2006, 13(6):1093-1100.

24. Schmidt M, Gerlach F, Avivi A, Laufs T, Wystub S, Simpson JC, Nevo E, Saaler-Reinhardt S, Reuss S, Hankeln T, et al: Cytoglobin is a respiratory protein in connective tissue and neurons, which is up-regulated by hypoxia. J Biol Chem 2004, 279(9):8063-8069.

25. Hankeln T, Ebner B, Fuchs C, Gerlach F, Haberkamp M, Laufs TL, Roesner A Schmidt M, Weich B, Wystub S, et al: Neuroglobin and cytoglobin in search of their role in the vertebrate globin family. J Inorg Biochem 2005, 99(1):110-119.

26. Nakatani K, Okuyama H, Shimahara Y, Saeki S, Kim DH, Nakajima Y, Seki S, Kawada N, Yoshizato K: Cytoglobin/STAP, its unique localization in splanchnic fibroblast-like cells and function in organ fibrogenesis. Lab Invest 2004, 84(1):91-101.

27. Hankeln T, Burmester T: Neuroglobin and Cytoglobin. In The Smallest, Biomolecules, Diatomics and their Interactions with Heme Proteins. Edited by: Ghosh A. Elsevier BV; 2008:203-218.

28. Xinarianos G, MCRonald FE, Risk JM, Bowers NL, Nikolaidis G, Field JK, Liloglou T: Frequent genetic and epigenetic abnormalities contribute to the deregulation of cytoglobin in non-small cell lung cancer. Hum Mol Genet 2006, 15(13):2038-2044

29. Shaw RJ, Hall GL, Woolgar JA, Lowe D, Rogers SN, Field JK, Liloglou T, Risk JM: Quantitative methylation analysis of resection margins and lymph nodes in oral squamous cell carcinoma. $\mathrm{Br} J$ Oral Maxillofac Surg 2007, 45(8):617-622.

30. Shivapurkar N, Stastny V, Okumura N, Girard L, Xie Y, Prinsen C, Thunnissen FB, Czerniak B, Frenkel E, et al: Cytoglobin, the newest member of the globin family, functions as a tumor suppressor gene. Cancer Res 2008, 68(18):7448-7456.

31. Stupp R, Mason WP, van den Bent MJ, Weller M, Fisher B, Taphoorn MJ, Belanger K, Brandes AA, Marosi C, Bogdahn U, et al: Radiotherapy plus concomitant and adjuvant temozolomide for glioblastoma. $N$ Engl J Med 2005, 352(10):987-996.

32. Wilden J, Moore I: Histological Factors in the Prognosis of Malignant Glioma. Brain Oncology: Biology, Diagnosis and Therapy. Martinus Nijhoff, Dordrecht 1987.

33. Bertout JA, Patel SA, Simon MC: The impact of $\mathrm{O} 2$ availability on human cancer. Nat Rev Cancer 2008, 8(12):967-975.

34. Hochachka PW, Buck LT, Doll CJ, Land SC: Unifying theory of hypoxia tolerance: molecular/metabolic defense and rescue mechanisms for surviving oxygen lack. Proc Natl Acad Sci USA 1996, 93(18):9493-9498.

35. Laufs TL, Wystub S, Reuss S, Burmester T, Saaler-Reinhardt S, Hankeln T: Neuron-specific expression of neuroglobin in mammals. Neurosci Lett 2004, 362(2):83-86.

36. Ostojic J, Sakaguchi DS, de Lathouder Y, Hargrove MS, Trent JT, Kwon YH, Kardon RH, Kuehn MH, Betts DM, Grozdanic S: Neuroglobin and cytoglobin: oxygen-binding proteins in retinal neurons. Invest Ophthalmol Vis Sci 2006, 47(3):1016-1023.

37. Chen $X Q$, Qin LY, Zhang CG, Yang LT, Gao Z, Liu S, Lau LT, Fung YW, Greenberg DA, Yu AC: Presence of neuroglobin in cultured astrocytes. Glia 2005, 50(2):182-186.

38. Emara M, Salloum N, Allalunis-Turner J: Expression and hypoxic upregulation of neuroglobin in human glioblastoma cells. Mol Oncol 2009 3(1):45-53.

39. Hankeln T, Wystub S, Laufs T, Schmidt M, Gerlach F, Saaler-Reinhardt S, Reuss S, Burmester $\mathrm{T}$ : The cellular and subcellular localization of neuroglobin and cytoglobin - a clue to their function? IUBMB Life 2004, 56(11-12):671-679.

40. Ostojic J, Grozdanic S, Syed NA, Hargrove MS, Trent JT, Kuehn MH, Kardon $\mathrm{RH}$, Kwon $\mathrm{YH}$, Sakaguchi DS: Neuroglobin and cytoglobin distribution in the anterior eye segment: a comparative immunohistochemical study. J Histochem Cytochem 2008, 56(9):863-872.

41. Ostojic J, Grozdanic SD, Syed NA, Hargrove MS, Trent JT, Kuehn MH, Kwon YH, Kardon RH, Sakaguchi DS: Patterns of distribution of oxygenbinding globins, neuroglobin and cytoglobin in human retina. Arch Ophthalmol 2008, 126(11):1530-1536.

42. Schmidt M, Laufs T, Reuss S, Hankeln T, Burmester T: Divergent distribution of cytoglobin and neuroglobin in the murine eye. Neurosci Lett 2005, 374(3):207-211.

43. Olive PL, Trotter T, Banath JP, Jackson SM, Le Riche J: Heterogeneity in human tumour hypoxic fraction using the comet assay. Br J Cancer Suppl 1996, 27:S191-195.

44. Vaupel P, Schlenger K, Knoop C, Hockel M: Oxygenation of human tumors: evaluation of tissue oxygen distribution in breast cancers by computerized O2 tension measurements. Cancer Res 1991, 51(12):3316-3322.

45. Fordel E, Thijs L, Martinet W, Schrijvers D, Moens L, Dewilde S: Anoxia or oxygen and glucose deprivation in SH-SY5Y cells: a step closer to the unraveling of neuroglobin and cytoglobin functions. Gene 2007, 398(12):114-122.

46. Allalunis-Turner MJ, Franko AJ, Parliament MB: Modulation of oxygen consumption rate and vascular endothelial growth factor mRNA expression in human malignant glioma cells by hypoxia. $\mathrm{Br} \mathrm{J}$ Cancer 1999, 80(1-2):104-109.

47. Genin O, Rechavi G, Nagler A, Ben-Itzhak O, Nazemi KJ, Pines M: Myofibroblasts in pulmonary and brain metastases of alveolar soft-part sarcoma: a novel target for treatment? Neoplasia 2008, 10(9):940-948.

48. Vordermark D, Brown JM: Endogenous markers of tumor hypoxia predictors of clinical radiation resistance? Strahlenther Onkol 2003 , 179(12):801-811.

49. Shigematsu A, Adachi Y, Matsubara J, Mukaide H, Koike-Kiriyama N, Minamino K, Shi M, Yanai S, Imamura M, Taketani S, et al: Analyses of expression of cytoglobin by immunohistochemical studies in human tissues. Hemoglobin 2008, 32(3):287-296.

50. Kivela AJ, Kivela J, Saarnio J, Parkkila S: Carbonic anhydrases in normal gastrointestinal tract and gastrointestinal tumours. World J Gastroenterol 2005, 11(2):155-163.

51. Barrett T, Troup DB, Wilhite SE, Ledoux P, Rudnev D, Evangelista C, Kim IF, Soboleva A, Tomashevsky M, Marshall KA, et al: NCBI GEO: archive for high-throughput functional genomic data. Nucleic Acids Res 2009, , 37 Database: D885-890.

52. Burmester $T$, Hankeln $\mathrm{T}$ : What is the function of neuroglobin? J Exp Biol 2009, 212(Pt 10):1423-1428.

53. Duong T, Antao S, Ellis NA, Myers SJ, Witting PK: Supplementation with a synthetic polyphenol limits oxidative stress and enhances neuronal cell viability in response to hypoxia-re-oxygenation injury. Brain Res 2008, 1219:8-18.

54. Fago A, Mathews AJ, Brittain T: A role for neuroglobin: resetting the trigger level for apoptosis in neuronal and retinal cells. IUBMB Life 2008, 60(6):398-401.

55. Li RC, Morris MW, Lee SK, Pouranfar F, Wang Y, Gozal D: Neuroglobin protects PC12 cells against oxidative stress. Brain Res 2008, 1190:159-166.

56. Raychaudhuri S, Skommer J, Henty K, Birch N, Brittain T: Neuroglobin protects nerve cells from apoptosis by inhibiting the intrinsic pathway of cell death. Apoptosis 2010, 15(4):401-411.

57. Allalunis-Turner MJ, Barron GM, Day RS, Fulton DS, Urtasun RC: Radiosensitivity testing of human primary brain tumor specimens. Int $J$ Radiat Oncol Biol Phys 1992, 23(2):339-343.

58. Parliament MB, Allalunis-Turner MJ, Franko AJ, Olive PL, Mandyam R, Santos C, Wolokoff B: Vascular endothelial growth factor expression is independent of hypoxia in human malignant glioma spheroids and tumours. Br J Cancer 2000, 82(3):635-641.

59. Johnston AL, Lun X, Rahn JJ, Liacini A, Wang L, Hamilton MG, Parney IF, Hempstead BL, Robbins SM, Forsyth PA, et al: The p75 neurotrophin receptor is a central regulator of glioma invasion. PLOS Biol 2007, 5(8) e212. 
60. Koch CJ, Howell RL, Biaglow JE: Ascorbate anion potentiates cytotoxicity of nitro-aromatic compounds under hypoxic and anoxic conditions. $\mathrm{Br} J$ Cancer 1979, 39(3):321-329.

doi:10.1186/1475-2867-10-33

Cite this article as: Emara et al:: Hypoxic regulation of cytoglobin and neuroglobin expression in human normal and tumor tissues. Cancer Cell International 2010 10:33.

Submit your next manuscript to BioMed Central and take full advantage of:

- Convenient online submission

- Thorough peer review

- No space constraints or color figure charges

- Immediate publication on acceptance

- Inclusion in PubMed, CAS, Scopus and Google Scholar

- Research which is freely available for redistribution

Submit your manuscript at www.biomedcentral.com/submit 